\title{
The Meso-Level: Social Life and Trade on a Metropolitan Shopping Street
}

If one walks down Karl-Marx-Straße in the Neukölln district of Berlin, for example observing the street life at the busy crossing of Rathaus Neukölln, the intersection of one subway line and several bus lines, one can see shoppers, residents, local employees, and commuters on their way to work or nearby schools squeezing out of the subway exits. Most sidewalks are heavily crowded with people, whereas others are almost empty. At second sight, one might also notice that the lively sidewalks host a variety of smaller and medium-sized stores of many kinds: bakeries, flower stores, hair and nail salons, grocery stores, butchers, several takeaways, diners and restaurants, cafés, textile and shoe stores, cell phone stores, as well as chain stores, bank branches, and supermarkets; the opposite sidewalks host block-long chain stores or vacant warehouses. This observer of the people strolling up and down Karl-Marx-Straße might also ask why these people choose - perhaps unconsciously - particular sidewalks. Taking a third look, the observer might discover that many passersby greet and nod to people inside of the stores, waving their hands through the stores' front windows, while others focus more on the products in the displays on their way to work or home or back. A look through the stores' front windows into the salesrooms and gastronomic spaces presents an even more differentiated picture of not only who uses the street and its spaces, but also in what ways and for what purposes: abridged, supply, or social exchange.

This short observation of Karl-Marx-Straße's sidewalk life introduces the businesses' urban context. Streets are more than just places of economic and social life. Many cities and neighborhoods are identified by their main streets, whose 
respective characters reflect local populations, their needs and lifestyles. These main streets also represent the populations' perceptions of the city, the neighborhoods, and their character and how people relate or identity with them. Main streets are often shopping streets. These are the places where abstract concepts, such as globalization and diversity, take a concrete, local form. Shopping streets are thus places of everyday encounter, where the practice of shopping allows strangers to meet and face one another in (often) routine, familiar, and thus safe environments (Shamsuddin/ Ujang 2008).

In Berlin, the major streets most associated with the city's image are the prestigious four-lane, tree-lined boulevards such as Unter den Linden or Kurfürstendamm. But likewise important are the city's radial thoroughfares, crowded shopping streets that form the cultural, social, and commercial hearts of Berlin's many districts. Four of such streets are Müllerstraße in Wedding, Schloßstraße in Steglitz, Turmstraße in Moabit, and Karl-Marx-Straße in Neukölln. ${ }^{12}$ These streets typically have a mixed housing stock, with commercial spaces on the ground floor and rental apartments on the floors above. Most of the buildings are pre-war, although scattered in between are public housing developments from the 1960s, 70s, and 80s. Commercially, one might find street vendors, niche and specialty stores, franchise and chain stores, as well as small shopping centers. All have high car, bike, and pedestrian traffic. ${ }^{13}$ These streets are important for Berliners, not only as places to buy everyday supplies and specialty items, but also as historically significant socio-cultural strongholds. However, due to their increased promotion in guidebooks, travel blogs, and city marketing materials, these streets are also becoming important places for tourists. Previously only interested in Berlin's grand boulevards, city visitors are increasingly spending their time on the district shopping streets. ${ }^{14}$

Whereas Schloßstraße and Friedrichstraße have experienced substantial upscaling and residential turnover in the recent decades, the populations of Müller-, Turm- and Karl-Marx-Straße remain highly diverse in terms of ethnic, income, and age groups even in spite of recent upgrading developments. Following years of disinvestment and store closure, new urban renewal programs have rebuilt these

12 "Neukölln" is used to refer to the whole district and "North Neukölln" refers to the neighborhoods surrounding the field site street.

13 According to the planning office's preparatory examination of the retail development along Karl-Marx-Straße, the majority of the street's users come from the neighborhoods immediately surrounding the street and to a slightly lower extent from the southern parts of the district and the adjacent district of Kreuzberg.

14 For the city of Berlin's categorization of main shopping streets as well as further descriptions of each street, see: Berlin (n.d.). Einkaufsmeilen in Berlin, https://www. berlin.de/special/shopping/einkaufsmeilen/, accessed 04/06/2016. 
three streets socially, culturally, physically, and commercially. These changes have attracted international capital and investors as well as new, more affluent, residents.

This chapter thus provides the historical background of my field site - KarlMarx-Straße. For the detailing of its urban, retail, and social developments in the next parts, I start with an ethnographic anecdote on the re-opening of Karl-MarxStraße's central square.

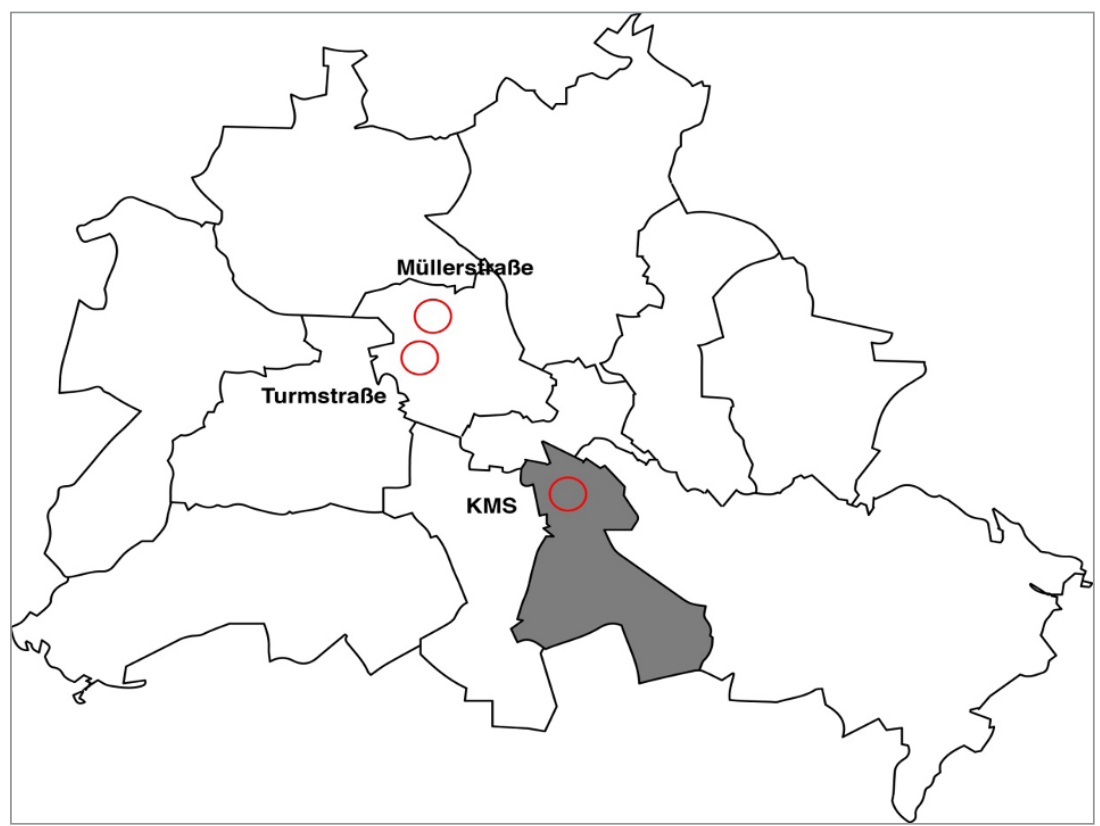

Fig. 3 Map of three of Berlin's 'main shopping streets', incl. Karl-Marx-Straße

On the sunny spring afternoon of April $28^{\text {th }} 2014$, after years of extensive renovations and construction, the new central square of Karl-Marx-Straße finally opened to the public with a big event. The street and opposite sidewalk was crowded with shoppers, families, and cars - a typical Saturday afternoon. On the square itself, a crowd of around one hundred people lazed on benches before a stage or waited in line for a Bratwurst or an ice cream, chatting and observing each other. The same sidewalk theater could be observed once again at a festival on May $23^{\text {rd }}$. The district administration erected a central stage that loomed over a handful of small stalls. 
Within these booths, "local entrepreneurs"15 offered Mediterranean and German food, while local cultural and social institutions - such as kindergartens, day cares, community, and senior centers - distributed information materials and free sweets. Religious groups and local party representatives also handed out brochures and booklets. On stage, a puppet theater delighted child with a play featuring local policemen, the mayor, and an urban developer. ${ }^{16}$ Nestled in the first few rows of the benches, the children cheered and shouted toward the stage. Afterward, young girls in colorful costumes climbed shyly onto stage to perform a Ukrainian folklore dance. They were announced by the head of the municipal development office, who spoke in a thick Neukölln dialect. Children ran among the benches in front of the street, while hipsters gathered in front of the new coffee joint, drinking organic lemonade and locally micro-brewed beer. The plaza itself is covered with a

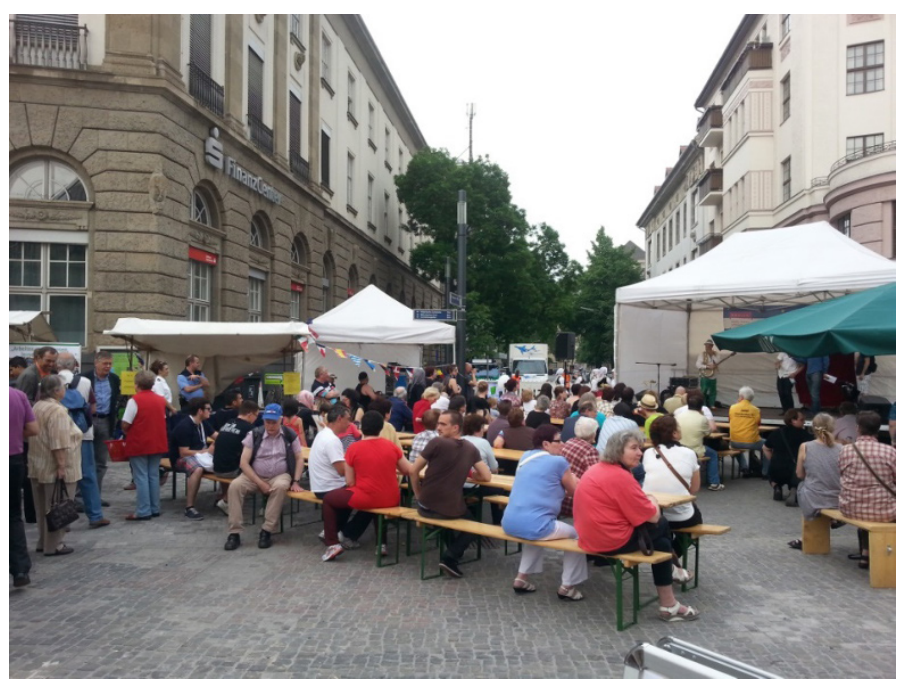

Fig. 4 Re-opening of new square on 5/23/2014

15 These entrepreneurs did not necessarily come from the local shopping street, but from the entire district of Neukölln, most of whom were of German origin.

16 State Secretary Engelbert Lütke-Daldrup, District Mayor Heinz Buschkowsky and City Councilor Thomas Blesing declared the street's "new centerpiece" open for the public, cf. Senatsverwaltung für Stadtentwicklung und Umwelt (n.d.). Eröffnung des AlfredScholz-Platzes in Neukölln, http://www.stadtentwicklung.berlin.de/aktuell/kalender/ kalender_detail.php?id=3749, accessed 08/25/2014. 
a variety of differently colored stones in the floor, forming a triangle and offering only a few new, modern benches in a very clean style, a couple of young trees and only some garbage cans on the border to the high trafficked street. Sitting on the modern benches, women and men of different age groups and ethnic origin relaxed next to one another, chatting and commenting on the performances. All had very skeptical looks on their faces throughout both events.

Karl-Marx Straße was once stigmatized by a bad reputation for too many vacant lots, cheap "ethnic" stores, "one-sided offers," low purchasing power, run-down appearance, and high traffic pollution (urban planner, $1.733 \mathrm{ff}$.). However, the celebrations for the new central square exemplify the shift in attention now given to the street on behalf of the district government, the media, and people living outside the area. Different Berlin and Neukölln daily newspapers as well as the two local television channels promoted and praised the opening of the new square as a "new place that invites guests to stay and can be used for different events," "the residents are enthusiastic," "for Neukölln people, a welcomed investment," 17 which is in line with the local speakers, the district's mayor, the heads of the urban planning department, the City Management, and the local steering committee.

The district authorities had postponed the opening of the new central square several times, leading to an unbearable traffic situation for many commuters and pedestrians, and causing grief for the surrounding businesses. The construction site affected the three small surrounding streets, cutting them off from both car and foot traffic. For more than two years, the entries were blocked to a neighboring pharmacy, a bar, a warehouse, a bank, a language school, a bike shop and a café. Despite having received some compensation, these business owners suffered from decreased traffic. Speaking of the end result, the skeptical locals on the benches said, "this place is not for us;" "no shade at all;" "only for young people;" and "too noisy." On the other hand, some mothers with strollers praised the new sidewalks, saying they eased pedestrian traffic on the busy street.

The newly built square created a bigger space $\left(2500 \mathrm{~m}^{2}\right)$ for local events and festivities (offered by the local authorities, not by private initiatives) than before, when it was more or less an extended sidewalk, crossed by car traffic to the side-streets. As the result of a local art competition, the enlarged pedestrian area was covered with eight differently-colored bricks in a triangle pattern; the colors, however, are difficult to distinguish. During both festivities, visitors searched (partially unsuccessfully) for the ground mosaic said to have $67.8 \%$ grey stones for the German population, 13.6\% basalt stones for the population groups from the Near and Middle East, 9\%

17 TV Berlin (04/29/2014). Eröffnung des Alfred-Scholz-Platzes gefeiert, http://www. youtube.com/watch?v=9rtCiqn $1 V Z$ o, accessed 06/23/2014. 
for Eastern Europe, 4.4\% for Western Europe, 1.1\% for Africa, 1\% for the Far East, and $0.9 \%$ for the US. ${ }^{18}$ The mosaic, however, does not accurately represent the diversity of the local population living around the new square. Whereas Neukölln has 325,716 inhabitants from more than 160 nations, most of those who come from other countries live in the northern part of the district and around Alfred-ScholzPlatz and Karl-Marx-Straße. ${ }^{19} 53 \%$ percent of North-Neukölln's population comes

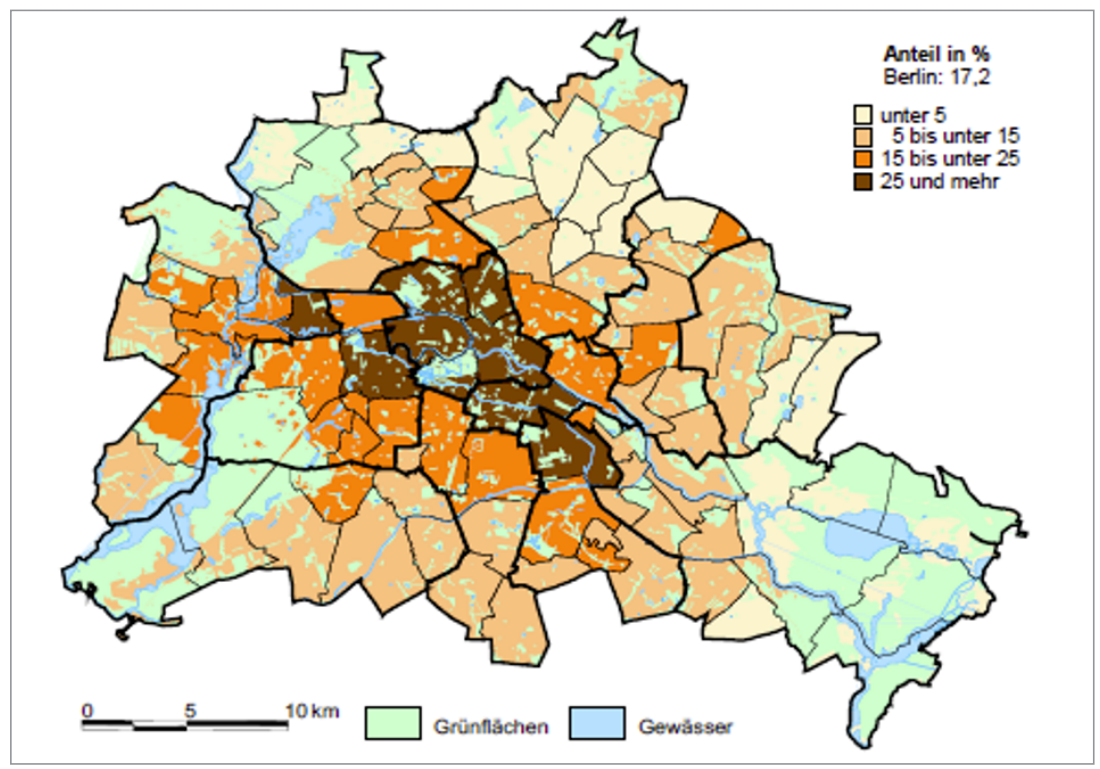

Fig. 5 Percentage of "foreigners" ${ }^{20}$ compared to Germans living in Berlin

18 Aktion! Karl-Marx-Straße (05/2014). Was bedeuten die Steine? http://www.aktion-kms. de/files/2014-05-20_infoasp_2-seitig.pdf, accessed 04/09/2016.

19 District Administration of Neukölln. Statistics for 12/31/2014, http://www.berlin.de/ ba-neukoelln/ueber-den-bezirk/zahlen-und-fakten/statistische-daten/einwohnerzahlen/, accessed 04/07/2016.

20 The German Federal Office of Statistics (2011: 5) defines foreigners as all persons who are not German within the meaning of Art. 1, paragraph 16,1 GG, this means, all persons who do not hold the German nationality. These include the stateless persons and persons with undetermined nationalities. Germans, who hold also a foreign nationality at the same time, are not part of the so-called foreign population. In other words, foreigners are people with a non-German passport. Cf. https://www.destatis.de/DE/Publikationen/ 
from outside of Germany: $11 \%$ from Turkey, $9 \%$ from the Middle East ${ }^{21}$ (mainly from Lebanon, Syria, and Palestine), 5\% from Poland, 4\% from the former Yugoslavia, and $2 \%$ from the former USSR. ${ }^{22}$

The following maps indicate the high diverse proportion of people with migration backgrounds as well as people with a non-German passport around Karl-MarxStraße. In the first map, the dark red color indicates areas with more than $25 \%$ of "foreigners"; in the second map, the red refers to "people with migration background."23,

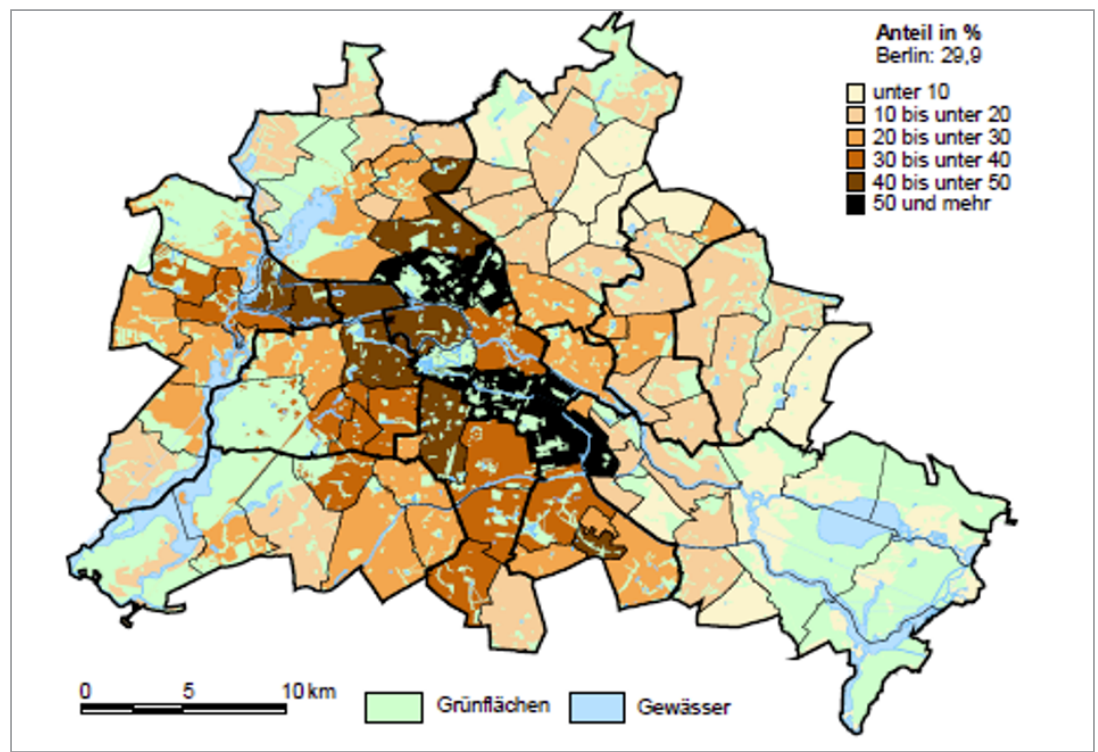

Fig. 6

Percentage of "people with migration background" among all Berlin population according to the Berlin districts

Thematisch/Bevoelkerung/MigrationIntegration/AuslaendBevoelkerung2010200117004. pdf?__blob=publicationFile, accessed 04/18/2016.

21 Members of Arabic League are Egypt, Algeria, Bahrain, Dschibuti, Iraq, Yemen, Jordan, Qatar, Comoros, Kuwait, Lebanon, Libya, Morocco, Mauretania, Oman, Saudi-Arabia, Somalia, Sudan, Syria, Tunisia, United Arab Emirates, and the Palestinian areas.

22 District Administration of Neukölln. Statistics for 12/31/2013, http://www.berlin.de/ ba-neukoelln/migrationsbeauftragten/bevoelkerungsstruktur.html, accessed 06/23/2015.

23 Statistik Berlin Brandenburg (n.d.). Statistische Berichte for 12/31/2015, https:// www.statistik-berlin-brandenburg.de/Statistiken/statistik_SB.asp?Ptyp=700\&Sageb $=12041 \& \mathrm{creg}=\mathrm{BBB} \&$ anzwer $=11$, accessed 04/07/2016. 
For the local authorities, the long-awaited re-opening of the public square was meant to be the "coronation" of the local urban development program Aktion KarlMarx-Straße..$^{24}$ This program aims to transform the street into a "young, dynamic and international" corridor, with open spaces for "encounter, experience, action." The amenities of the new street were meant for both the local population as well as for tourists. ${ }^{25}$ The renewal programs offer many social and physical measures ${ }^{26}$ designed to "improve" the area, such as traffic guidance measures, street and façade refurbishment, social networking opportunities, language and family-care classes, and other educational and qualification programs. Nevertheless, ethnographic observations at the two events reveal significant fears on behalf of local residents and business owners concerning rising rents, displacement, and increased alienation from their places of residence and work. ${ }^{27}$ For instance, the prices of the micro-brewed beer and focaccias on offer exceeded most visitors' wallets and thus didn't match with the needs of the local population groups, leading to the aforementioned sense of alienation.

The celebration itself was promoted as a "multicultural" event, with a program and gastronomic offer designed to mirror and capitalize on the diversity of local ethnic groups. Nevertheless, at the event itself, no local longstanding businesspeople were present, and only few guests seemed to have a migration background. Again, the people on the benches seemed alienated from the happenings on stage as well as with the changes made to "their" street: "I cannot connect with this" was one of the main statements I heard at both events.

This event description underlines the controversial and contested nature of Karl-Marx-Straße's current outlay and appearance. In an atmosphere of heightened economic competition, rising commercial and residential rents, and a high media coverage of recent gentrification, long-term residents and business owners show highly skeptical and hesitant behavior toward any new construction site, business opening, and street marketing measure. On the one hand, as gentrification hotspots still not yet fully gentrified, the street and its surrounding neighborhoods are

24 Notably, upon its reopening, the plaza was renamed from Platz der Stadt Hof to AlfredScholz-Platz in honor of the districts' first Social-Democratic Mayor of the district, a man deposed by the Nazis in 1933.

25 Aktion! Karl-Marx-Straße (n.d.). News, http://www.aktion-kms.de/projekte/alfredscholz-platz-frueher-platz-der-stadt-hof, accessed 06/23/2014.

26 The local neighborhood management programs deal more with social changes, whereas the local City Management and Aktion Karl-Marx-Straße are in charge for the more physical measurements.

27 See for further projects Aktion! Karl-Marx-Straße (n.d.). Projekte. http://www.aktion-kms. de/projekte/, accessed 08/18/ 2014. 
being accused (by residents, outsiders, journalists, and politicians alike) of being a "ghetto" and of hosting "parallel societies" (cf. Friedrich 2012; 2013). On the other hand, many such stigmatizing discourses particularly affect local migrant populations and social-disadvantaged residents by marking them as a political "problem" (Friedrich/ Schultes 2013). These discourses encourage urban renewal programs designed to create "better" social and commercial mixtures. This could create community empowerment, but more often, the discourses have a racist and exclusionary undertone.

\subsection{The Street's Physical History}

The following narrative of Karl-Marx-Straße's residential and commercial histories that is constructed uses written accounts as well as personal - often nostalgic - oral accounts from business owners, city officials, urban planners and residents (old and new). These histories vary considerably depending on who is speaking and to whom they are addressing - in this case, always myself. I also draw on as many perspectives as possible, using newspaper articles, (non-) academic books on district's history, as well as on the statistics from municipal and federal administrative bodies. My aim is not to present one complete history, but rather to uncover the aspects of local residential and commercial histories that have contributed both to the present-day aggregation of commercial facilities and to the current challenges of urban renewal and neighborhood change. This description of the field site street provides an important meso-perspective of the city, where interactional practices between diverse people "are refined within a distinct area" (Hall 2015: 28). This allows for a further in-depth analysis of the concrete interactional or contact sites on this street, the sampled businesses. ${ }^{28}$

The description of Karl-Marx-Straße, as the meso-level context for the subsequent analysis of the businesses, follows Jennifer Robinson's (2006: 3) call for grounding urban studies in a greater diversity of cosmopolitanisms: It is essential that researchers account for the great diversity of everyday experiences found in the lives of urban dwellers. Researchers should therefore follow their research subjects to their everyday places and through their everyday routines. Hence, Karl-

28 Thereby, the methodological challenge is to relate the city, the street, and then the concrete business sites as both bounded and connected spaces, gathering information on all three levels from various sources. All maps, pictures and statistics present only a single moment in time, but following Hall (2015: $28 \mathrm{f}$.), I try to recognize also the rhythms of change over longer periods that together transform the street and its residential and commercial composition. 
Marx-Straße is one of these seemingly unspectacular and "ordinary" ${ }^{29}$ places in Robinson's understanding.

Karl-Marx-Straße was originally a three-kilometer Hauptstraße (Main Street) that connected the villages of Britz and Rixdorf ${ }^{30}$ to the city of Berlin. In the $18^{\text {th }}$ century, it was surrounded by fields and acres. By the early $19^{\text {th }}$ century, the street was a location for merchants, workshops, and two-to-three story houses, many with late-classicist facades. The street developed into a thriving shopping street by the end of the $20^{\text {th }}$ century, and then, by the early $21^{\text {st }}$ century, into the current neighborhood with a widely known residential and commercial diversity.

In the $18^{\text {th }}$ century, the street was called Berlinerstraße, indicating its linkage to the city center, and then Bergstraße due to the nearby Rollberge hills, the latter of which still gives the neighboring public housing complex Rollbergviertel its name. By the late $19^{\text {th }}$ century, Bergstraße had become Rixdorf's main commercial street, home to many longstanding businesses. Many, including the pharmacy studied in this book, still exist today. ${ }^{31}{ }^{32}$ Industrialization and the construction of working-class housing estates increased the street's everyday social and commercial life. The contemporary narratives and images of the street are still influenced by its industrial built, cultural, and social heritage as well as its history as a "proud working class area." The Gründerzeit street was also popular for its numerous entertainment facilities, such as Saalbau Neukölln (today a theater, café/restaurant and concert venue), the adjacent party halls in today's Passage (today an art house cinema, cafél restaurant and opera), and other large taverns and restaurants.

29 Robinson (2006: 1) describes the world as comprising a huge variety of ordinary cities, which "are all dynamic and diverse, if conflicted, arenas for social and economic life." The ordinary-city-approach takes this world of ordinary cities as a starting point and "attends to the diversity and complexity of all cities." By understanding cities as ordinary, she argues, research needs to follow the diversity of urban experiences on the ground and thus to ground urban theory more therein (This is one of the reasons why this research works with a Grounded Theory Method Approach, see Chapter 4).

30 Rixdorf was the old village core around which Neukölln developed. Protestant refugees from Bohemia settled in the village of Rixdorf around 1737. Most of the remaining village-like buildings and farm houses were built by the late $18^{\text {th }}$ century and circle around the settlement's central square, Richardplatz. For more, see: Neukölln im Netz (n.d.). Berlin-Neukölln, http://www.neukoelln-online.de/denkmale/rixdorf/start.htm, accessed 04/22/2016.

31 The store owners repeatedly mention a luggage store in the interviews, often as a symbol for the popular image of the street as a shopping destination in the $20^{\text {th }}$ century.

32 However, after having been on the street for more than 100 years the pharmacy had to close due to a rent increase of $250 \%$ in late 2017 . Since then, the business space is vacant (October 2018). 


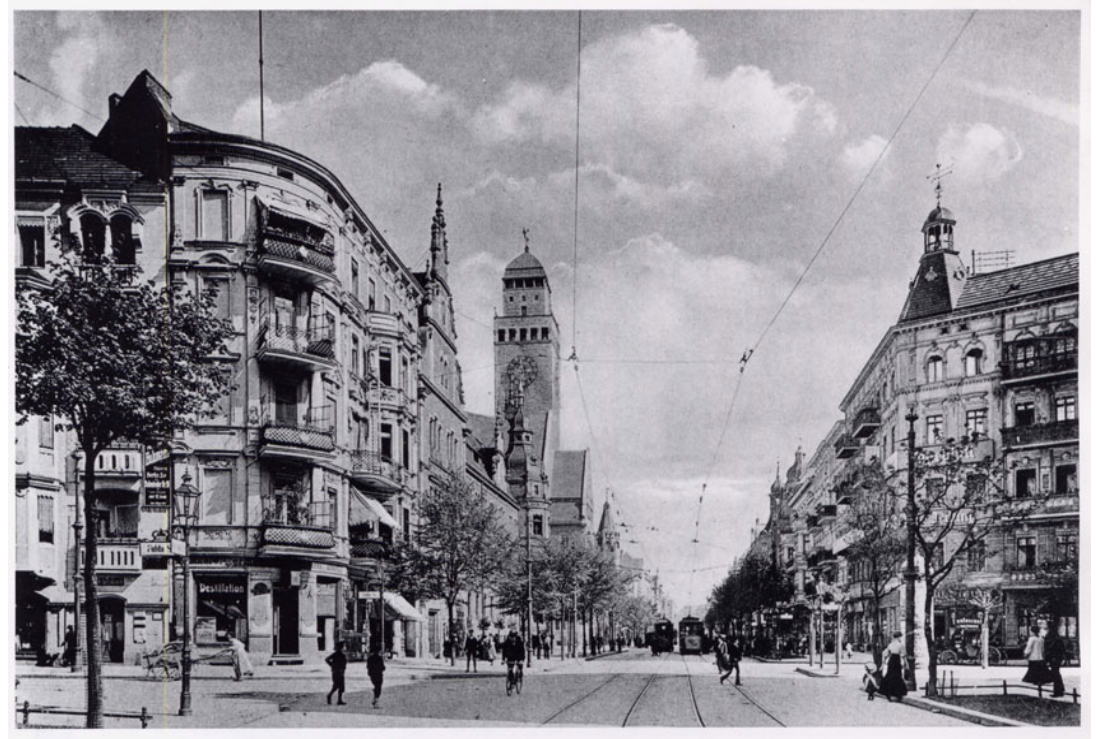

Fig. 7 Berliner Straße (today Karl-Marx-Straße) $1910^{33}$

The construction boom that took place from 1900 to 1913 filled the street's vacant lots with the "classic" Berlin five-story perimeter block development; this gave the street its still-current look and design. In the same period, the district's city hall, administration buildings, and post office were built, all of which likewise contribute to the street's historical character. Throughout the first and second world wars, the Social-Democratic Party (SPD) and the Communist Party (KPD) held the majority in the local district assemblies, resulting in tremendous district-wide physical demolitions by the Nazis in 1933. After the Nazis occupied the district's city hall that year, they forced many longstanding Jewish businesses to close down and leave the district. Despite the vast demolitions that followed the bombing of the city during the war, the majority of the district's perimeter developments have survived until today.

33 Source: Friedmann, F. (10/13/2011). Zeitreisen. Mythos Karl-Marx-Straße, http://www. neukoellner.net/zeitreisen/mythos-karl-marx-strasse/, accessed 04/15/2016. Courtesy: Museum Neukölln 
The street was renamed as Karl-Marx-Straße (1947) during the Soviet occupation, connecting the terrible memories of the national-socialist regime with the district's long history as a vibrant working class neighborhood (Hentschel/ Blokland 2015: 123). (The district ended up mostly in the Western part of the city, however.) In the 1950s, under the new land-use plan, the street was developed as the main supply center for the southern districts of West Berlin: New commercial buildings filled in the bombed-out lots and new warehouses added to the street's commercial functions. The building of the Berlin Wall in 1961 cut off nearly half of the street's customers, employees, and suppliers. The Wall also caused the street to lose its function as a public traffic line and a major thoroughfare. In spite of these problems, the local business people managed to maintain the street's commercial character. Businesses nevertheless did suffer because of the Wall, and many residents left the area, causing many longstanding businesses and cultural institutions to close down over the next decades. This paved the way for new migrants, many of the so-called "guest-workers" from Turkey and Italy, to move into the area.

Until 1989, Karl-Marx-Straße was Berlin's third-strongest (in terms of popularity and customer numbers) shopping street with more than 260 different retailers, service providers, and gastronomic facilities - both individually owned and chain operated (Hüge 2010: 41). At the time, the majority of these businesses were owned by ethnic Germans, ${ }^{34}$ whereas in 2008 around one-third of the business were owned by migrants from Turkey, Poland, China, Vietnam, and the Middle East (Kayser et al. 2008: 34 ff.). And since then, ownership diversity has increased in terms of the educational, ethnic, and socio-economic backgrounds of the owners. The local urban renewal commissioner frames the structure of businesses in the following way:

and this patchwork rug [of ethnic businesses], well, they all also speak German well, of course, but the flag is missing, so we had around $\mathbf{5 0}$ different languages and also almost everywhere [along the street], the entire big density was represented. Is it now ethnic retail just because they sell German shoes, which are probably made in China and get their label in Italy and then are offered in a German store and [with] a Turkish vendor, I mean what is ethnic trade?! (1. 180-185 $)^{35}$

While the commissioner is aware of the diverse ownership, he depicts the street's diversity in a way that doesn't seem to affect his work with and for the business people.

34 "Ethnic German" describes someone born in Germany of those of German descent. This term is not applied to returning migrants of German descent.

35 I translated all quotes from my interview partners. In order to best represent the voice of the interviewees, the translations are direct, rather than free or interpretive. 


\section{2 "Trade is change." ${ }^{36}$ The Street's Retail History and its Current Changes}

Retail and trade are constantly undergoing structural changes as a result of intensified competition as well as demographic and socio-cultural changes (Hangebruch/ Krüger 2014: 6). In the $20^{\text {th }}$ century, individually owned specialty stores, such as those offering groceries, clothing, shoes, repair services and other daily goods prevailed on the Karl-Marx-Straße, making it an attractive shopping location for West Berlin's southern and eastern districts. As a commercial location, Karl-MarxStraße changed significantly after fall of the Berlin Wall in 1989. Initially, the street received more shoppers from the East, but then saw a significant downturn in the mid-1990s. This was caused by area unemployment, the out-migration of the employed working-class and middle-class families, and competition from nearby new shopping malls.

This loss of potential and regular customers challenged many longstanding businesses (Hüge 2010: $23 \mathrm{ff}$.), many of which had to close down. The independently owned specialized retailers in particular faced significant closures. Until the mid2000s, the new businesses that opened in their place were predominantly franchise and chain stores as well as discount shops. The street has seen a 50\% loss in sales since the fall of the Berlin Wall for all the remaining retailers and service providers, and as Berlin's third strongest shopping street, it still faces comparatively high vacancy rates (Hüge 2010: 42).

The local district authorities designed several urban renewal programs to tackle the street's decline. The programs, which initially focused on physical improvements, aimed to reverse the buildings' and sidewalks' dilapidation as well as improve the negative reputation of the whole district as a place of vandalism and crime. Klaus Engeln, the former head of the urban renewal working group Aktion Karl-MarxStraße, framed the street's situation in the late 1990s and early 2000s as "all in all: no economically and consumption friendly atmosphere. It should surprise nobody, if one or the other internally departs from Neukölln" (Klaus Engeln 2001 in Hüge 2010: 42). During this time, the ethnic German owners of small independent shops, in particular, criticized the decline of the formerly thriving street and threatened to move their businesses to another district. A butcher interviewed for this study, who owns one of the businesses that barely managed to survive this low point, describes the neighborhood situation in the mid-2000s in the following way:

36 "Handel ist Wandel" (Hangebruch/ Krüger 2014: 6). 
[T] he bottom point of the development in Neukölln for me personally was in 2004, $\mathbf{2 0 0 5}^{37}$, when it really was on the rocks, because too many regular customers died out or moved away, many moved away [they] were scared of other nationalities or were worrying and said noooo, I won't send my kid to a kindergarten or in a school where $90 \%$ of the school mates have foreign roots, this won't lead to nothing. And of course also the negative media coverage, many just moved then and said, no we need to move to better city districts, or we want to go away from here, we can't stand this anymore, this is too noisy, this is too dirty, this is too too too foreign, right. And then [they] just moved away [...] So particularly in Neukölln, you realize immediately social cuts, at least in conversations, because many people that live here are affected by it [the social cuts], right, this is still a working-class district, where only people live, who work in simple activities, who are low wage workers and they kept their savings back and that just made life for us difficult [...] but starting with 2006 it [turnovers] surged. 2005 we really hit bottom rocks, that was the very first time that I had to dismiss two employees because of a lack of revenues, this has never happened to me, not before and not later on. (1. 90 -148.)

Many other interviewees, including both business people as well as local officials, similarly described late 2005 and 2006 as a bad period for the area and a time they seriously considered leaving the neighborhood. Most stayed, either hoping for better times, or because they felt rooted in the community, or simply due to lack of resources. Other problems that the street faced were the closure of two local major warehouses, a terrible traffic situation, and a lack of parking. The local officials described the sidewalk as unwalkable, narrow, and overfilled with merchandise and signage from stores looking to drum up business. This downturn, with increased unemployment, poverty, and vacancy rates continued until the late-2000s (Hüge 2010: 38).

The street's everyday life has been affected not only by demographic change and urban renewal (see Chapter 2.3.), but also by shifting local investment strategies and changing shopping patterns. Just as many inner-city shopping streets, and despite their acknowledged function as provisional centers, Karl-Marx-Straße is also affected by a decline in economic activity due to disinvestment and the low local purchase power in some of the rather deprived neighborhoods, when middle and higher income residents moved out of these neighborhoods (Häußermann 2011: 274, Häußermann/ Kapphan 2002).

Furthermore, the rising numbers of chain stores and discounters that have high revenues affect the smaller suppliers' sales, but also increasingly displace them in most inner-city neighborhoods, including Neukölln. In the most recent survey of the street, conducted by the City Management (the district's commercial support

37 While the butcher sees his personal low-point in 2004/2005, he considers 2006 as the low-point for the entire North Neukölln area. 
agency), between the train stations Hermannplatz and Neukölln, Karl-Marx-Straße has 38 take-away-food stores, 20 fashion stores, 15 bakeries, 14 cell phone stores, 14 pharmacies, 14 call shops, 13 one-dollar-stores, 13 bars, 12 banks, 11 jewelers, and 11 hair salons, and a handful of flower shops, banks, grocery stores, nail salons, and hardware stores, most of which are franchise of chain stores (cf. Hentschel/ Blokland 2015).

In general, the German retail and local supply sector is characterized by stagnating or declining sales on the one hand and the expansion of retail space on the other. Higher competition, rising commercial rents, shifting consumer preferences and shopping behaviors, all further affect the decline of many of the traditional and small-scale specialty stores. ${ }^{38}$ However, on Karl-Marx-Straße this holds true only for the strip of shops around the city hall, where the majority of chain and franchise stores are located.

Resulting from these factors, independent businesses are increasingly displaced by chain stores, which often offer a less localized range of products and which also depend less on local knowledge of the neighborhood and its residents. Since many of the chain stores' employees work in different branches all over the city, they often do not develop a sense of connection with the neighborhood or the local regular customers. In addition, due to the more standardized operational sequences, the chain stores' employees often offer less space for social interaction that goes beyond the economic transaction than many of their individually owned counterparts. ${ }^{39}$ The loss of affluent residents along with other more corporate retail developments over the last decades has contributed to the domination of chain stores accompanied by shop vacancies on Karl-Marx-Straße and many other inner-city shopping streets.

38 The interviewed business people name rising commercial rents, demographic changes and the respectively different shopping preferences, the local shopping mall and chain stores as well as the far-reaching construction sites as their main business threats. The local officials state shifting consumer preferences and increase in sales spaces along with the unwillingness to upgrade their businesses as the main reasons for the smaller businesses' struggle (e.g. urban planner, $1.561 \mathrm{ff}$.; urban commissioner, 1. $146 \mathrm{ff}$.).

39 This is according to interviewed local officials, who cooperate mostly with the managers of the chain stores. 


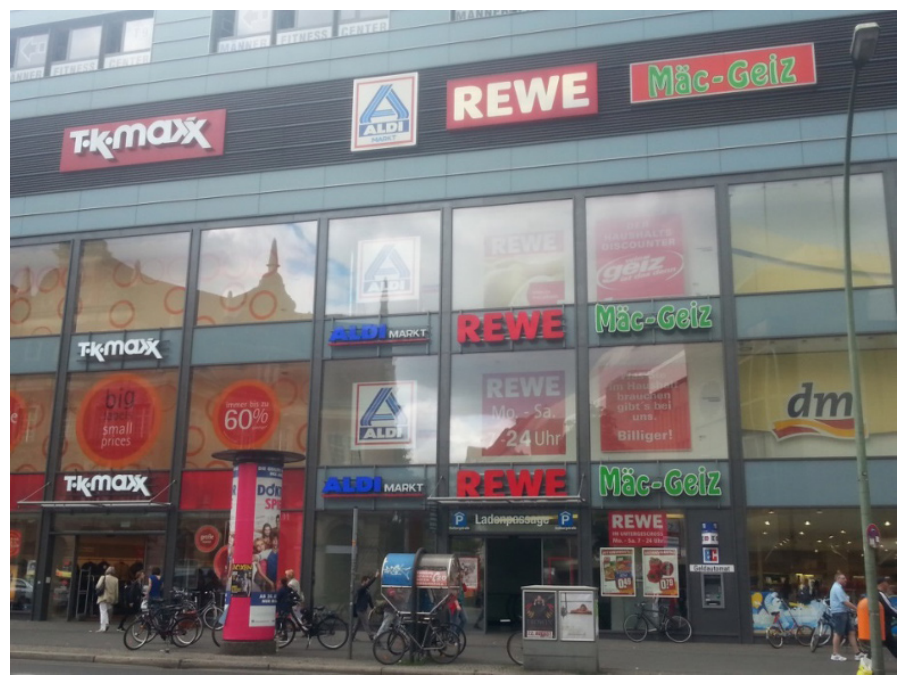

Fig. 8 The chain stores' main block on Karl-Marx-Straße

Put together, today, the individually owned businesses on Karl-Marx-Straße are challenged by the loss of their customers due to the disinvestment in the past years and the subsequent out-migration of many previous customers. At the same time, they must also cope with the recent re-investment, shifting demographics, new corporate competitors, and rising commercial rents.

In addition, e-commerce has also greatly affected retail and shopping practices, which in turn, has further led to changes on the street. After years of continuous structural changes such as new organizational structures, new distribution chains and marketing alongside an increased demand for bigger sale space, comprehensive offers at any time of the day, and a more lifestyle -oriented event experience, stationary retail is now challenged by increasing online purchases and consumption: Whereas e-commerce made up $7.3 \%$ of all retail in 2009, in 2015, that figure had already moved to $11.7 \%$. The goods most often purchased are clothing, books, and electronic devices. Only very few groceries and drugs are ordered online in Germany at the time of writing. ${ }^{40}$ One can see this change mirrored in the patterns of store closures on the Karl-Marx-Straße. Most of the stores that have closed offer precisely

40 BEVH (2015). Aktuelle Zahlen zum Interaktiven Handel. Auszug aus der bevh-Studie "Interaktiver Handel in Deutschland B2C", http://www.bevh.org/markt-statistik/ zahlen-fakten/, accessed 04/07/2016. 
these types of products: electronic devices, books, and clothing. Those retailers who remain offer mostly supply products and services, which are less threatened by the rise of online shopping, such as grocery stores, bakeries, butchers, flower stores, cell phone stores, and eating places. E-commerce also changes customer-staff-interaction, since most staff knows that many customers only frequent stores to get informed about new products, but buy them online. In addition, shopkeepers may not depend exclusively on stationary trade for their sales and thus might reduce consultation for and interaction with customers in the stores.

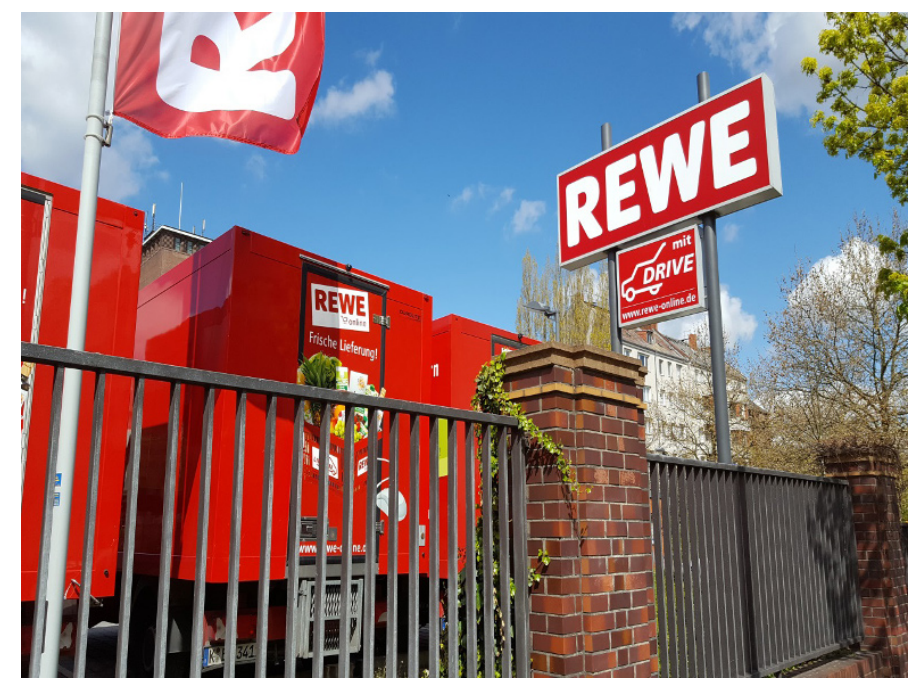

Fig.9 A local supermarket offers online shopping and delivery services

The challenges posed by e-commerce do not affect only Karl-Marx-Straße, but impact all shopping locations in Berlin and Germany: According to the German Association for Trade (HDE), many inner-city retailers complain of declining customer traffic. Current structural changes force the stationary retailers to "play to their strengths," bettering the physical, material, and spatial aspects of the shopping experience. A 2014 survey of city retailers indicates that in order to do this, most business owners depend on customer events (54\%), an experience-oriented store design (52\%), and innovative stock (40.3\%). However, according to the HDE, 
retailers must nevertheless combine online and offline trade in order to keep their businesses afloat. ${ }^{41}$

Those suppliers on Karl-Marx-Straße who have remained open have had to adapt their business strategies to compete with the online market and new consumption patterns, offering online services or at the very least, maintaining an online presence. One of the local butcher shops, for instance, has a successful online shop that takes and fills orders for its sausages from all over Europe. The butcher started online services in 2006, the year the neighborhood hit rock-bottom and the business needed to enlarge their clientele in order to survive. Even if only to use the internet to advertise, most of the Karl-Marx-Straße shops had to expand online to contend with their larger, corporate competitors. The restaurants, in particular, try hard to promote their spaces online (often for family or business events) to balance customer loss or low turnovers by promoting online their spaces. But the interviewed owners also return to extended consultations in order to make on-spot shopping more attractive.

In order for their businesses to survive, it is important that owners offer "experience-oriented" shopping spaces for customers who pursue shopping as a leisure activity. ${ }^{42}$ One would imagine that events on Karl-Marx-Straße, such as the aforementioned festivals, would be valuable for drumming up local business; however, many retailers abstain from participating because they disagree with these events as well as the measures taken by the city to improve the street's overall shopping experience. For one, many of these comparatively formal events are aimed at target groups incongruous with their own clientele, e.g., late night shopping or cultural events such as $48 \mathrm{~h} \mathrm{Neukölln}$ or Nacht und Nebel Neukölln that draw primarily younger, lifestyle-oriented visitors. Secondly, participating in the beautification, event measures, and other more experience-oriented shopping events are often too costly (in terms of financial and time resources) for many of the smaller retailers and service providers:

[For the late-night-shopping] they ask us to keep [the store] open for a longer time, first nobody asked me in advance if I'm able to do this, no artist would come to us [anyway], so why should I keep the business open? Because the people won't schlep themselves with a flower bouquet through the streets at $10 \mathrm{pm}[\ldots]$ they are not paying

41 HDE (2014). Handel setzt im Strukturwandel auf Einkaufserlebnis, http://www.einzelhandel.de/index.php/presse/aktuellemeldungen/item/124465-handel-setzt-im-strukturwandel-auf-einkaufserlebnis, accessed 08/22/2014.

42 GfK (2015). GfK-Studie zu den Rahmenbedingungen für den Einzelhandel in 32 Ländern Europas, http://www.gfk.com/de/insights/press-release/einzelhandelssituation-in-den-europaeischen-krisenlaendern-verbessert/, accessed 11/25/2015. 
attention that the small businesses, not mine necessarily, it could be the pharmacy, that they get performances. We can't afford to pay 500 or 1500 or 5000 Euro for such a weird light installation (Flower store owner, 1. 444-451).

Many businesspeople therefore prefer to rely on their own experience and knowledge, repeating measures that have previously proven successful. One flower store, for instance, threw a backyard party, for which the owner also invited the local officials, neighboring business colleagues, and interested customers (cf. l. 613 - 618).

On the other hand, the adjacent local shopping mall continues to increase its customers and sales numbers with its regular and widely-promoted events, most of which are partially supported by the local authorities and the urban renewal programs. The mall and its retailers compete thus with a structural advantage, while the other shop owners as well as some of the local officials argue that attention must be given to create a balanced branch and tenant mix and to ensure their compatible integration into the urban space. Otherwise, the power and economic relations that already favor the corporate chain stores will produce further incompatibilities for the independent businesses. The independent businesses also mourn the closures of the warehouses, such Quelle or Hertie, which once stood as anchors on Karl-MarxStraße, attracting shoppers from all over Berlin. Whereas the warehouses worked with the smaller businesses to improve the street as a whole, the shopping center's events seem to exclude small businesses and problematically draw all the customers inside the mall. This problem is not just limited to events, however: The shopping center routinely directs customers away from street-front stores, particularly when temperatures drop and the weather turns rainy:

if people decide to shop in the center because they find a parking spot there or because they feel disturbed by the rain, I can't help it, but the street's diversity, the [shopping] center can't compensate this diversity, but the comfortableness and they [the shoppers] are so lazy, this is a serious problem for us (Pharmacy owner, 1. 155-159).

The competition with the shopping center, the discounters ${ }^{43}$ and e-commerce has forced store owners to recognize that the social aspect of shopping in brick and

43 Most store owners name the fall of the wall as a crucial point in time for changes in shopping behavior and the local commercial structure. However, in the 1990s, discounters started to cover Neukölln, Berlin, and other German inner-city and rural areas, evermore changing shopping patterns. However, Krüger et al. (2013: 27 f.) found for all stores of daily supply, regardless if corporate (chain, discount, franchise, etc.) or individually owned, that inner-city residents decide primarily for those stores that are in the close surrounding of their residential places (and even more for single households and particularly senior households), have a wide variety of offers, and attractive prices. 
mortar stores is unique and desirable. Thus, many owners focus on promoting these desirable qualities in their daily operations, sometimes to the extent of creating distinct marketing or business strategies. For instance, some shops make stronger efforts to engage their senior clientele, who depend on neighborhood facilities for their daily shopping needs; these owners offer specific products, targeted advertisements, and even provide special services, such as benches, restrooms, and specially trained staff. ${ }^{44}$ Likewise, some pharmacies tailor their offers to address common maladies in the neighborhood. A pharmacist, for instance, related how she regularly offers free blood-pressure readings as well as special lessons on managing cholesterol, high blood pressure, rheumatism in the interview. She also arranges for Turkish translation when she offers special sessions on children's diseases in order to reach local parents without German language skills.

One of the primary motivations for frequenting brick and mortar shops is the social component. Customers thus desire shopping environments, infrastructure, and design that facilitate meeting friends, acquaintances, and neighbors (Feinberg et al 1989: 61). In my observations, it became clear that families, for example, tend to primarily frequent cafes, restaurants, and shops that offer play corners, diaper-changing areas, and child-friendly atmospheres. These facilities make it easier for parents to visit with their friends and to initiate interaction with other parents. So from this perspective, Karl-Marx-Straße's consumers seem to request a high variety of high quality products in (but not necessarily) close proximity, just as the promoted products and services outrank proximity for all kinds of urban residents. However, as reported by the store owners, the local higher income groups may also travel and shop to wherever the high quality products are offered.

All in all, the street has experienced waves of investment and disinvestment. Global and national structural changes have changed its residential and commercial composition over the course of the $20^{\text {th }}$ and early $21^{\text {st }}$ century. While the signs of impending decline stretch back to the 1980s, they are also related to broader changes in retail practices as well as to changes in the investment strategies of urban renewal and retail developers.

Atmosphere, design, and friendliness and patience of the employees follow the primary criteria for the selection of a particular shopping location. In this context, social interaction with staff and personal service as well as small or flexible offers are particularly important for senior customers (Krüger et al. 2013: $28 \mathrm{ff}$.).

44 Some of the sampled businesses take part at the "Seniorensiegel" campaign, which labels businesses that offer special shopping conditions for senior customers, including offering benches and other facilities to sit down and take a rest, customer restrooms, trained and specialized personal, parking spots for handicapped people, et cetera. 


\section{3 "This is the free market. We set only the political framework. ${ }^{\prime \prime 5}$ The History of Local Urban Renewal}

The decline around Karl-Marx-Straße started in the 1970s with deindustrialization; the first working group dedicated to street renewal was founded in 1979. Until the 1990s, this group of local actors aimed to increase the street's attractiveness by organizing street parties, planting trees, and fighting for sidewalk extensions and other beautification measures.

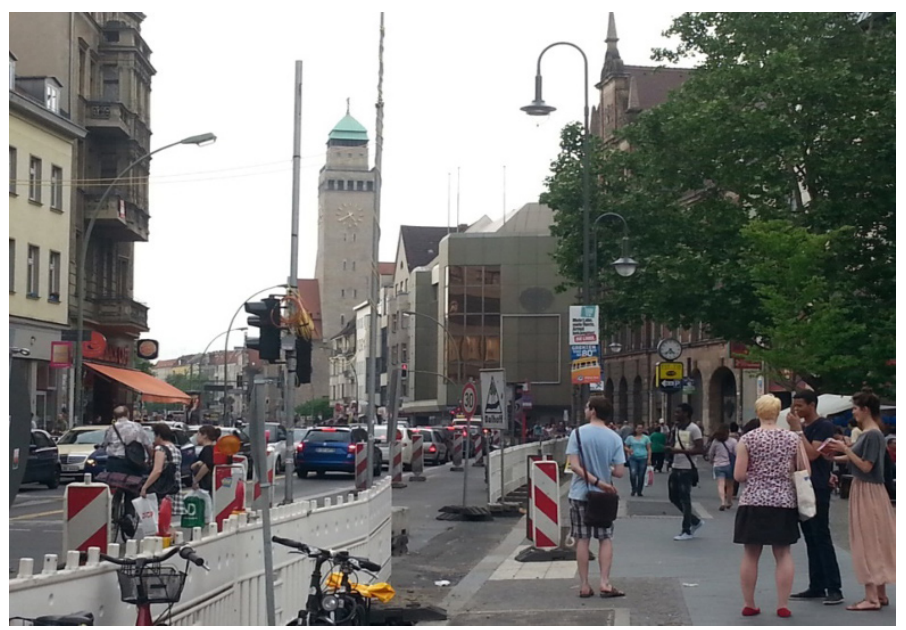

Fig. 10 Crowded sidewalk with construction site on Karl-Marx-Straße

In the 1990s and early 2000s - and despite the skepticism of many longstanding retailers - local authorities considered developing shopping malls in a last-chance effort to "save" Karl-Marx-Straße. In his support of the shopping malls, the then Neukölln mayor said, "who doesn't participate in the change won't survive the next millennium." ${ }^{36}$ Thus in 2007, Karl-Marx received its first shopping mall: the Forum

45 Urban planner, 1. $281 \mathrm{f}$.

46 Fuchs, C. (07/08/1998). Das Forum Neukölln soll die angeschlagene Einkaufsmeile aufwerten Eine Chance für die Karl-Marx-Straße, http://www.berliner-zeitung.de/ archiv/das-forum-neukoelln-soll-die-angeschlagene-einkaufsmeile-aufwerten-einechance-fuer-die-karl-marx-strasse,10810590,9452340.html, accessed 7/25/2014. 
Neukölln (today Neukölln Arcaden), with over 60 businesses and a square footage of $27,000 \mathrm{~m}^{2}$. The mall was considered to be supporting the urban planners' measures to increase the street's appeal as well as its customer numbers. However, the majority of the street's smaller businesses rejected and protested against the establishment, fearing the heightened competition. Indeed, as the local business owners feared, simply expanding the amount of available retail space did nothing to increase the local people's purchase power and led to the negative redistribution in the favor of the chain stores and shopping mall. ${ }^{47}$ However, as reported by the interviewed store owners, many smaller businesses managed to survive by providing to both local and city-wide customers, because the street did already enjoy the reputation as a city-wide shopping destination for clothing and shoes, repair services, and groceries. This reputation was still in place when the main urban renewal programs started in the mid-2000s.

During the late 1990s and early 2000s, Neukölln was also widely considered Germany's most deprived district. With the economic decline immediately after the Berlin wall came down, the government stopped subsidizing the local industries and Neukölln lost 20,000 jobs within ten years. The urban renewal programs under effect targeted primarily the eastern Berlin districts and not Neukölln. In addition to the new shopping mall, local and national planning authorities therefore developed several "regeneration" schemes aimed at transforming the area and upgrading its commercial structure. Various programs were developed, some focusing at different scales (city, street, neighborhood), and some focusing on different outcomes, often labeled as revitalization, upgrading, or renewal. Until today, the concrete urban interventions of the subsequent urban renewal programs cover particular streets, such as Karl-Marx-Straße, adjacent Hermannstraße or Sonnenallee, or single Kieze $e^{48}$, or entire neighborhoods or districts. But in the 1990s and 2000s, the city spent concentrated on renewal in other parts of the city and widely neglected Neukölln. The neighborhoods around Karl-Marx-Straße remained among the few areas in

47 Treichel, T./ Paul, U. (10/31/2002). In Berlin sind zahlreiche neue Shopping-Center entstanden. $\mathrm{Zu}$ viele, meint der Einzelhandelsverband, http://www.berliner-zeitung. de/in-berlin-sind-zahlreiche-neue-shopping-center-entstanden--zu-viele--meint-dereinzelhandelsverband-viel-platz-zum-einkaufen-15485868, accessed 04/19/2016.

48 Berliners use the term "Kiez" to designate small neighborhoods within city districts. Importantly, the term indicates an area with a commonly accepted identity and sense of belonging among its population, which is often named after their main streets or squares. Residents have a sense of tangible natural or built boundaries. The surrounding Kieze of KMS are Donaustraßenkiez, Richardplatz Kiez, Rollbergkiez, Reuterkiez, Körnerkiez, but the interviewees and planning authorities also describe Karl-Marx-Straße as one Kiez itself. 
Berlin where housing prices stayed at a lower level than in the already upgraded eastern and northern inner-city neighborhoods (such as adjacent Kreuzberg, or Prenzlauer Berg, Mitte, and Friedrichshain), but also where the local purchasing power decreased due to the loss of jobs (Huning/ Schuster 2015).

In 1999, the Berlin Senate Administration for Urban Development and Neukölln's district authorities began implementing different urban renewal schemes (including the Neighborhood Management programs (Quartiersmanagement)), in several Kieze around Karl-Marx-Straße, choosing neighborhoods as well as smaller-scale traffic units based on their socio-demographic and socio-economic statistics. ${ }^{49}$ In 1999, its umbrella program, the Socially Inclusive City Program (Soziale Stadt) also started. Local, federal, and national authorities further implemented programs responding to the area's physical decay; two of the most notable are Urban Restructuring West (Stadtumbau-West) and the implementation of Rehabilitation Zones (Sanierungsgebiete), aimed at the consolidation of the urban socio-spatial structures. ${ }^{50}$ In 2011, Karl-Marx-Straße along with Sonnenallee, which runs from in a southeast direction from Hermannplatz, have been designated as one such rehabilitation zone. ${ }^{51}$

In addition, the senate administration along with the district administrations also implemented the Active Centers Program (Aktive Zentren) in order to grow urban centers into an "attractive economic city or district centers" in 2008. One part of this program are the local City Management teams, who are in charge for the development of the Active Centers' commercial structures (Huning/ Schuster 2015: $744 \mathrm{f}$.). Karl-Marx-Straße's particular program is called Aktion! Karl-Marx-Straße (Aktion KMS) and is in charge of the street's economic and commercial development. These urban planners work closely with the urban renewal commissioner and planning departments responsible for organizing the local rehabilitation zone and other urban restructuring programs. Of all the urban planners working for the

49 The traffic units build the base for most of the German urban development and social programs. They were established in 2006 on the basis of the previous concept of social environments (Sozialräume) and are now called life-world oriented spaces (Lebensweltlich Orientierte Räume/ LOR). They aim to cover a spatial unit with a homogeneous life-world or milieu. See more on LORs: Berlin.de (n.d.). Planung Stadtwissen und Daten, http:// www.stadtentwicklung.berlin.de/planen/basisdaten_stadtentwicklung/lor/, accessed 02/24/2016.

50 Berlin.de (n.d.). Sanierungsgebiet Neukölln - Karl-Marx-Straße / Sonnenallee. http:// stadtentwicklung.berlin.de/staedtebau/foerderprogramme/stadterneuerung/de/karl_ marx_str/index.shtml accessed 02/19/2016.

51 For the reasons to turn Karl-Marx-Straße in a rehabilitation zone and target of the active center programs, see Aktion! Karl-Marx-Straße (n.d.). Ausgangslage, http://www.kmssonne.de/ausgangslage-und-ziele/ausgangslage, accessed 02/19/2016. 
different programs, it is the City Management's employees who interact most with the local business owners; however, as I will argue later, these employees focus the majority of their attention and resources on the owners of corporate chains and franchises (see Chapter 7).

Hence, following decades of decline and with the onset of these programs, the district suddenly "became an option for young starter households and middle-income groups who could no longer afford to live in areas such as Kreuzberg, Mitte, and Prenzlauer Berg, where rents had already been rising from a much higher level" (Huning/ Schuster 2015: 745, cf. Holm 2013). In 2012, the physical renovations began on the street: they began at the southeastern end and will continue to the northwest in the direction of Hermannplatz; the final reconstruction phase is scheduled to beginning in 2020. Right in the middle of the planned reconstruction zone, urban planners began to redesign the Alfred-Scholz-Platz simultaneously in 2012. ${ }^{52}$

All of the aforementioned programs belong to a wider framework of integrated urban development concepts (ISEK ${ }^{53}$ ), a framing concept/mechanism/program that structures the funding as well as the socio-political and daily working context for the urban planners assigned to these projects. The staff of the programs work under a shared motto that summarizes their vision of the street: "Young, colorful, successful - trade, encounter, experience (Jung, bunt, erfolgreich - handeln, begegnen, erleben)." This motto indicates a vision of the street that is clearly designed towards different demographics and businesses than its current commercial and residential diversity. Nonetheless and despite their different foci, measures, budgets, and target groups, all planners and municipal employees share this common vision and goal to "upgrade" (urban planner, 1. 252) the street. ${ }^{54}$

52 Aktion! Karl-Marx-Straße (n.d.). Meilensteine der [Aktion Karl-Marx-Straße], http:// www.aktion-kms.de/files/akms-imageflyer2012-barpdf.pdf.pdf, accessed 02/19/2016.

53 ISEK as Integriertes Stadtentwicklungskonzept represents the orientation framework for the long-term development of Karl-Marx-Straße and Sonnenallee with its main planning goals. See more: Aktion! Karl-Marx-Straße (n.d.). Integriertes Stadtentwicklungskonzept, http://www.kms-sonne.de/files/141009_isek-plan_kms-sonne_ausdruck_barr.pdf, accessed 02/19/2016.

54 As mentioned by all urban planners and their material, e.g. for Aktion KMS, see: Aktion! Karl-Marx-Straße (n.d.). Umbau der südlichen Karl-Marx-Straße, http://www. aktion-kms.de/projekte/umbau-karl-marx-strasse/suedliche-karl-marx-strasse/, accessed 02/24/2016. 


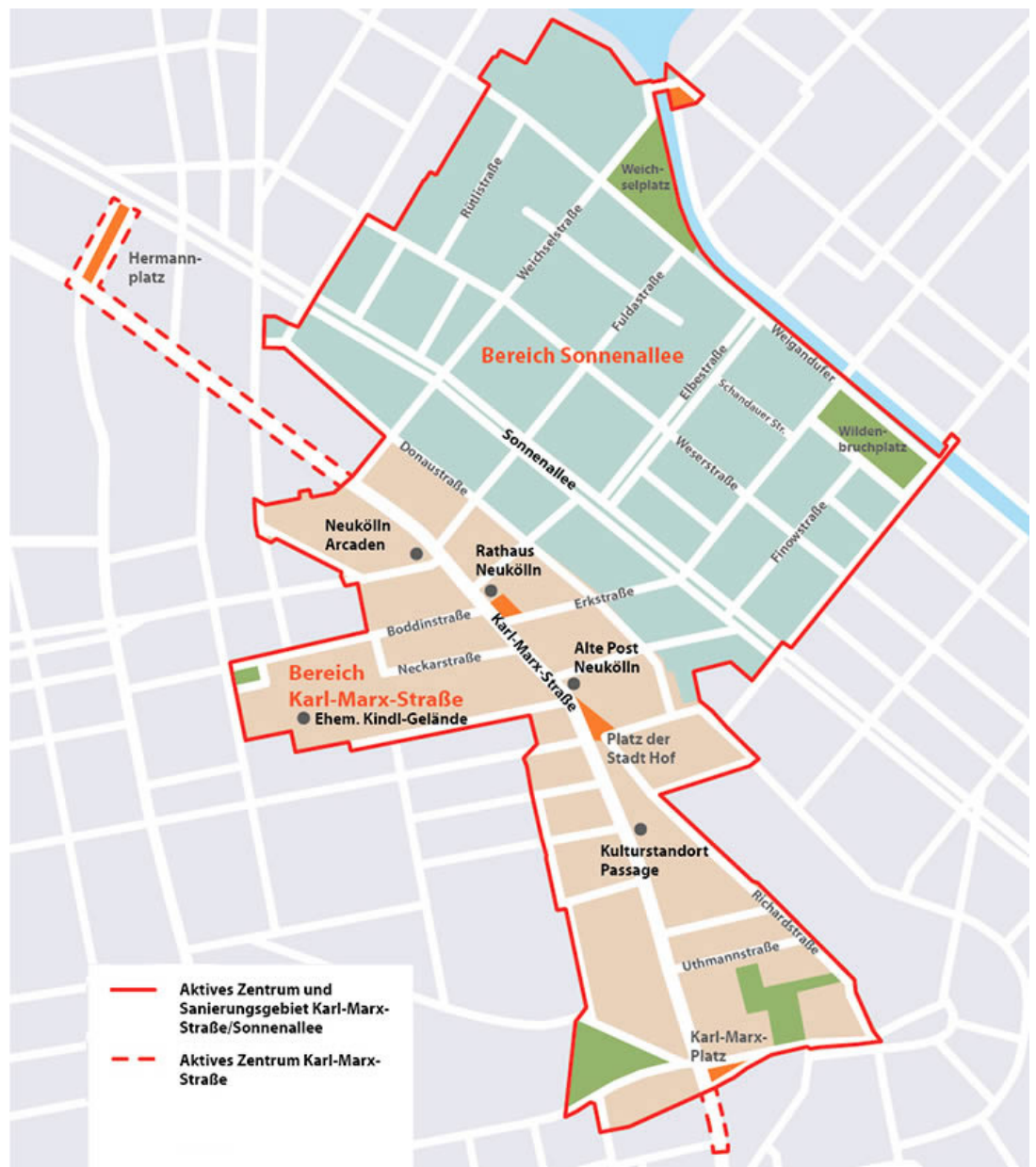

Fig. 11 Active Centers areas of Karl-Marx-Straße and Sonnenallee, divided by Donaustraße $\mathrm{e}^{55}$

55 Source: Aktion! Karl-Marx-Straße (n.d.). Karte, http://www.kms-sonne.de/files/karte. html, accessed 03/30/2016. Courtesy: BSGmbH. 
In the late 2000s, the urban renewal program Active Urban Centers ${ }^{56}$ (Aktive Stadtzentren) conducted an analysis of the street's strong and weak points, opportunities, and threats $(S W O T)$, in order to determine their future work on Karl-Marx-Straße. In this analysis, the authors argue that the street suffers primarily from heightened competition with nearby shopping locations (interestingly, also by the local shopping mall) and from a negative retail development characterized by high vacancy rates, low residential purchasing power, a disproportionate presence of discount stores, and a lack of anchor businesses, upscale gastronomic facilities, and independently owned businesses. Within the document, the planners celebrate the street's (past and current) ethnic diversity and its success as both a place of trade and residence; however, they predict further downturn and bemoan the population's low social status and the lack of acceptance and interaction between ethnic Germans and migrant groups. Finally, the planners concluded that in spite of the first signs of (apparently welcomed) gentrification, the area still suffers from a negative image, and a lack of networking among the business owners and landlords. With these concerns in mind, the planners developed their concepts and plans for the street's upgrading, which began in 2008 and continues until today. ${ }^{57}$

In the context and framework in which the business people work and live, this means that after the first phases of structural measures, the larger reconstruction moves gradually toward the city hall and Hermannplatz. When interviewed, the project's head planner confirmed that the program's plans may present certain "challenges" for many of the smaller businesses, but firmly rejects the idea that their measures also threat them: "This is the free market. We set only the political framework" (1. 281). In 2011, the Berlin government and the Senate extended the funding phase by fifteen additional years. To date, the Active City Center (with its Aktion KMS) is the current main urban renewal program for Karl-Marx-Straße. It aims to further improve the street's public space (such as the aforementioned Alfred-Scholz-Platz) and to beautify the local sidewalks and places. The program

56 This program was established in 2008 on order to improve the economic and structural situation of selected urban shopping streets. Thereby cooperation with local retailers and retail associations is seen as key to the street's development. The selected Berlin shopping streets are Karl-Marx-Straße/Sonnenallee, Marzahner Promenade, Müllerstraße, Turmstraße, City West, Wilhelmstad., cf. Berlin- das Hauptstadtportal (n.d.). Förderprogramme und -strategien für lebendige Quartiere, http://www.stadtentwicklung. berlin.de/staedtebau/foerderprogramme/aktive_zentren/, accessed 08/25/2014.

57 Cf. Aktion! Karl-Marx-Straße (n.d.). Der aktuelle Newsletter der [Aktion! Karl-MarxStraße], http://www.aktion-kms.de/sanierung/bereich-karl-marx-strasse/konzeptebis-2007/, (2008: 3), accessed 07/25/2014. 


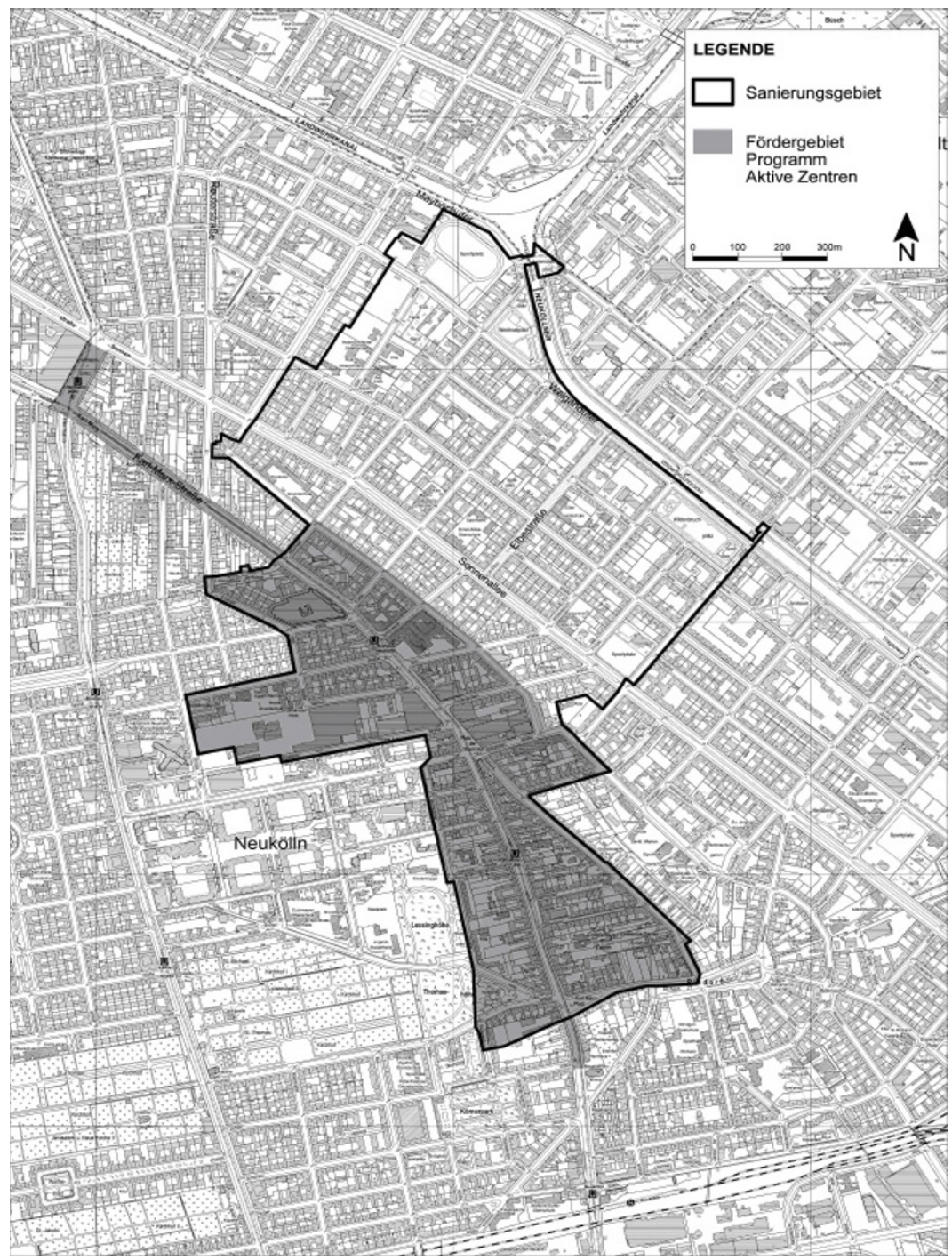

Fig. 12 Redevelopment area Karl-Marx-Straße/ Sonnenallee ${ }^{58}$

58 Source: Senatsverwaltung für Stadtentwicklung Referat IV C - Städtebauförderung / Stadterneuerung (2011): Zwölfte Verordnung über die förmliche Festlegung von 
finally aims to improve the commercial offers, the traffic situation, and in particular, the cooperation with house owners and selected business people. ${ }^{59}$

\section{4 "Now we go through a new change, now the employed come back."60 The Current Gentrification of Karl-Marx-Straße}

The vast changes that have occurred on Karl-Marx-Straße since the mid-2000s have spread beyond the analyses of local urban development offices to reach the local, national, and international media. The media tends to depict Neukölln as a district of extremes. On the one hand, it is a run-down, high-crime neighborhood home to a socio-economically deprived population and low-quality (migrant owned) businesses. On the other, Neukölln is shown as an up-and-coming area with beautifully restored Gründerzeit apartment blocks, quality boutiques and galleries, and niche stores; it is a desirable area where, in recent years, avant-garde artists and new middle-class families and entrepreneurs have come to settle. The latter narrative is the one preferred and used by the district authorities. For instance, in their quarterly magazine Broadway Neukölln (Autumn 2015), the renewal program describes Karl-Marx-Straße as follows:

You can see Karl-Marx-Straße's change even in the dark: Where they used to fold up the sidewalks at $6 \mathrm{pm}$, you can now see people strolling on the street after dark. And not only during the festival 48 hours Neukölln. ${ }^{61}$ Along with its cultural highlights,

Sanierungsgebieten und Festlegung und Ergänzung von Städtebaufördergebieten, p. 9. Courtesy: BSGmbH.

59 Aktion! Karl-Marx-Straße (n.d.). Der aktuelle Newsletter der [Aktion! Karl-Marx-Straße], http://www.aktion-kms.de/sanierung/bereich-karl-marx-strasse/vorbereitende-untersuchungen-nach-141-baugb/, accessed 01/10/2016.

60 Urban planner, 1. $531 \mathrm{ff}$.

6148 hours Neukölln is a festival for artistic projects from all of Berlin's art scene's sectors. The festival promotes art that addresses current social issues. As a festival for contemporary and political art, the aim is to broaden the understanding of art away from something that is only displayed in galleries and museums to something that connects, communicates, and has a social concern. The festival includes formal and informal places of art production and exhibition in Neukölln; however, the majority of participating spaces are newer galleries, cafés, bars, and show rooms. In recent years, the festival has turned from an art festival to a more nightlife-oriented festival, involving much more consumption than the mere public exhibitions and performances in 1999. 
the street also attracts people with its gastronomic offers [...] Who walks through the Neukölln center [Karl-Marx-Straße] will discover a lot: from the old-Berlin corner bar to the scene bar, from the Turkish vegetables store to the puppet-theatre-museum.

Life on Karl-Marx-Straße is diverse and exciting. ${ }^{62}$

Here the authors are celebrating the positive changes they have implemented on the street since 2008 as well as the future changes they envision, which they consider as increasing the street's attractiveness. In this publication, the authors from the urban renewal office repeatedly note that the district administration had already acknowledged the "bad condition" of the street in 2004, noting in particular its high vacancy rates and its lack of "attractive" businesses and anchor stores. At this point, they claim that they could thus start "sufficiently early" to apply for funding in order to remodel the street and develop the area according to their vision of a dynamic social and ethnic mix. Over the following years, and in cooperation with corporate networks, the district administration has widened the street's southern strip, added bicycle lanes and parking facilities, installed new lightening and façade decorations, and rebuilt and renamed the central square. All of these changes have paved the way for new gastronomic businesses, brands, and chain stores.

But upgrading the street also attracted comparatively more affluent home owners and renters. According to their publications in late 2015 (Broadway, Handelsnewsletter), the urban renewal agents in the local planning office and district administration felt satisfied with steps achieved toward developing their envisioned "young, colorful and dynamic" street. However, despite their honorable aim to develop the street for - and with - "all” the people working and living along Karl-Marx-Straße, the question remains if their conception of "all" also included the local business people - and if so, which ones, why, and how? (See Chapter 7.2.).

This gentrification had already begun years earlier. In 2010 - in line with the late 2000's statistical changes of the local population's socio-demographic structure the Berlin newspaper Tagesspiegel wrote:

Neighborhood Report Neukölln. District of Extremes. Neukölln is well known for social problems, violence, and a lack of integration into the rest of Germany. But yet: There's more optimism than ever before. And also more hype than ever before. ${ }^{63}$

See: 48 Stunden Neukölln (n.d.). Mission Statement, http://www.48-stunden-neukoelln. de/en/page/mission-statement, accessed 02/11/2016.

62 Aktion! Karl-Marx-Straße (2015). Broadway Neukölln, p. 2 f., www.aktion-Karl-MarxStraße.de, accessed 04/12/2016.

63 Guthke, J./ Vogt, S. (04/15/2010). Kiezreport Neukölln Bezirk der Extreme - Neukölln ist bundesweit Synonym für soziale Probleme, Gewalt und Integrations-Defizite. Und 
A year prior, in an article entitled, "Neukölln: Beyond the Hype," the English-language magazine Ex-Berliner asked: "[...] what is Neukölln really: colorful melting pot or Hartz IV ${ }^{64}$ ghetto [?]" ${ }^{65}$ Until today, most public attention focuses on Neukölln's "thriving" night life and the influx of international artists and students (e.g. Timeout magazine: "Neukölln: The Best Bits of Berlin’s Hippest "Hood"66, NY Times: "A Berlin Hub's Arty Spinoff," ${ }^{\prime} 7$ TAZ: "Wandel in Nord-Neukölln: Gentrifizierung? Hier Doch Nicht!"68, Tagesspiegel: "Gentrifizierung in Berlin: Hip, Hipper, Neukölln"69).

Since $2006,{ }^{70}$ Karl-Marx-Straße and the areas to its north have caught the attention of young entrepreneurs, who have opened their first businesses there, most often bars and other nightlife spots. This set in motion new waves of investment and media coverage that saw even more residents move to the area and more new businesses taking root and the area has seen a rise in commercial and residential rents. The media coverage along with the district's self-promotion attracted further investment, residents, business people, and tourists. For instance, the local administration's magazine for the renewal area around Karl-Marx-Straße is called Broadway Neukölln, and reports and advertises the new businesses, galleries, and arts events. In an interview with the (back in 2015 future) district mayor Franziska Giffey, both the mayor as well as the journalist argues that the current construction sites are necessary to develop Karl-Marx-Straße into a new "Broadway": "Karl-Marx-Straße should become Neukölln's Broadway, more space for pedestrians and bikers will be created." In addition, the future mayor, showing the journalists around KarlMarx-Straße, only visits the new businesses, such as the café (opened 2014) on

doch: So viel Aufbruch war selten. Und so viel Hype auch nicht, http://www.tagesspiegel. de/berlin/kiezreport-neukoelln-bezirk-der-extreme/1764120.html, accessed 06/25/2014.

$64 \mathrm{Hartz} I V$ is the German unemployment benefit paid after the first 12-18 months of unemployment.

65 Exberliner (05/20/2009). Neukölln: Beyond the hype, http://www.thelocal. de/20090520/19411, accessed 09/02/2014.

66 Clack, D. (10/15/2015). Neukölln: your guide to Berlin's hippest 'hood, http://www. timeout.com/berlin/en/things-to-do/navigating-neukoelln-your-guide-to-berlinshippest-hood, accessed 04/11/2016.

67 Wilder, C. (18/09/2009). A Berlin Hub's Arty Spinoff, http://www.nytimes.com/2009/09/20/ travel/20surfacing.html?_r=0, accessed 04/11/2016.

68 Brandenburg, K.W. (3/13/2012). Gentrifizierung? Hier doch nicht, http://www.taz. de/!5098498/, accessed 04/11/2016.

69 Frenzel, V. (11/30/2011). Hip, hipper, Neukölln, http://www.tagesspiegel.de/berlin/ gentrifizierung-in-berlin-hip-hipper-neukoelln/9152496.html, accessed 04/11/2016.

702005 and particularly 2006 are repeatedly named across all interviews as the neighborhood's nadir. 
the central and new designed plaza. ${ }^{71}$ However, in contrast to six kilometres long Karl-Marx-Straße, New York City's Broadway runs 25 kilometres long from the South of Manhattan up to the Bronx (and then an additional $29 \mathrm{~km}$ beyond the city borders), and has several very differently structured commercial strips. Broadway's strips target mainly tourists and other city visitors and the main shopping parts host almost exclusively big chain stores with highly overcrowded sidewalks in the front and very busy car and bus traffic and few marginalized bike lanes on the street space. This comparison of Karl Marx-Straße with Broadway reveals the exaggerated and unrealistic expectations of the journalists and their vision.

As the district's urban planner argues:

Well, I consider the current store owners as, those actors that are now here and occupy this space right now. But we plan strongly focused on the future, to around 15 years from now and we develop the coulisse or a space for activities. We explicitly don't serve the local actors but we have a development vision, we don't make improvements 'how to keep the street clean' or 'how to deal with security issues', [...] the development task is to generate a new vision of a space that takes over totally different functions [than now] and now there was a new profiling, where we reflected on a guiding vision, where we are become aware $[\ldots]$ which measures will be implemented and within a circle of indeed planners and experts we then tried to construct a guiding vision [...] trading, experiencing, encountering this means something different than in the past, where the street primarily had a shopping focus (Urban planner, 1. 243-250).

Well, we want distinct commercial structures or we want them to change [...] what we want is to change something in the sectoral mix, if we can, but this doesn't work via the traders but this works first of all via the land owner (Urban renewal commissioner, 1. 146-150).

In the framing of their jobs and the programs' working goals, the two urban renewal agents emphasize their support for the increase in wealthier residents and new businesses. They also make clear that their vision of the future Karl-MarxStraße may have to be developed without the cooperation of the current retailers. However, surrounded by talk of gentrification and an increase in anti-gentrification events, only few commercial establishments considered to be typical markers for gentrification have actually opened a shop on Karl-Marx-Straße itself until 2016 (Hentschel/ Blokland 2015: 128). ${ }^{72}$

71 RBB: Abendschau (02/05/2015), http://www.rbb-online.de/abendschau/archiv/archiv. html), accessed 03/31/2016.

72 From 2012 until April 2016, I counted four new bars, one club and gallery on Karl-MarxStraße, but many more (ca. 10) had also opened in the nearby vicinity. 
According to the city's rental market reports, from 2009 to 2015, the rents in the street's postal code area increased about $81 \% .{ }^{73}$ Despite this dramatic rent increase and the changing population, those living in North Neukölln still have comparatively low incomes. Although unemployment rates have decreased over the last couple of years, as of March 2016, Neukölln continued to have an exceptionally high unemployment rate (15.2\%), including a high percentage of both long-term and youth unemployed. In addition, Neukölln has a large number of residents (20.3\%) who receive welfare despite being employed ("working poor"). ${ }^{74}$ In fact, more than fifty percent of the area's children and teenagers grow up in poverty. ${ }^{75}$ This means that those who live in the area have a restricted purchasing power. It also menas that many residents depend strongly on local daily supply businesses and do not frequent any of the newer nightlife spots or boutique shops. This is the reality in this area despite being depicted in the media as "trend-setting" and "the center of all things hip."76

Most newcomers to Neukölln have higher educational backgrounds and incomes than the area's current population. More often they come from Germany or West and North Europe as opposed to many of the current residents who often have a Turkish, Arabic, or Polish migration background (cf. Chapter 2.1.). The shift in demographics is reflected by the new construction sites and the types of new businesses opening up in the area: organic stores, lifestyle cafés, upscale restaurants, galleries, and designer boutiques. The local business people also remark on these changes:

Many young people are coming, well students, now [...] yes! I already realize that there is so much just in the move. Which is beautiful, of course, who will then

73 Berliner Morgenpost (n.d.). Berliner Mieten seit 2009 - Wo sich die Preise verdoppelt haben, http://www.morgenpost.de/interaktiv/mieten/article136875377/So-stark-steigendie-Mieten-in-Berlins-Kiezen.html?config=interactive, accessed 02/06/2015.

74 Bundesagentur für Arbeit (n.d.). Arbeitsmarkt im Überblick - Berichtsmonat April 2016 - Neukölln, JC, https://statistik.arbeitsagentur.de/Navigation/Statistik/Statistik-nach-Regionen/SGBII-Traeger/Berlin/Neukoelln-Nav.html, accessed 04/12/2016.

75 Berlin - das Hauptstadtportal (n.d.). Die Entwicklung der Quartiere in Neukölln im Vergleich zu anderen (Teil-)Bereichen der Stadt Berlin in den Jahren 2007 bis 2009, http:// www.berlin.de/imperia/md/content/baneukoelln/2009pdf/qm/nklgutachten 190711. pdf?download.html, p.1, accessed 08/14/2014, and Berlin - das Hauptstadtportal (n.d.). Die Entwicklung der Quartiere in Neukölln im Vergleich zu anderen (Teil-)Bereichen der Stadt Berlin in den Jahren 2007 bis 2009, http://www.berlin.de/imperia/md/content/ baneukoelln/flyer/sozialdaten_bericht_final_august2012_1.pdf?download.html, p. 5, accessed 08/14/2014.

76 Clack, D. (10/09/2015). Neukölln: your guide to Berlin's hippest 'hood, http://www. timeout.com/travel/features/1277/neukolln-the-best-bits-of-berlins-hippest-hood, accessed 09/02/2014. 
some time, yes eventually they will stay, when they earn money later in the future (1. 214-218). [the neighborhood] has changed but when you're here every day, then you don't necessarily see that [change] anymore. Sure, it was better the old days, but everything was better in the old days and better is also very relative, right, these were different times and hmm, we can't regret bygone times, we need to cope with it. Sure this was, when I started here 17 years ago, there were banks around my business and the [long standing renown] luggage businesses and the book store, yes, these long standing businesses, and they aren't here anymore, of course, and that's the way it is and it's okay. It's also because of the loss of the customer clientele, of course, and it changed. Oh well, we have to stick it out (Flower store owner, 1. 498-503).

\subsection{Summary: "The main focus is on the site's development. ${ }^{177}$}

The previous subchapters presented the major changes that have occurred in the physical, commercial, and demographic structure of Karl-Marx-Straße as well as the development of the local urban renewal programs. Further attention was paid to the question of how local independent retailers and service providers have tried to adapt to changes in retail, trade, and shopping patterns. The discussed changes form the meso-context of Karl-Marx-Straße. I have also shown how the shop owners have been affected by the area's demographic and socio-economic changes and by the recent urban renewal programs.

The local retail and gastronomic businesses need to address the new consumer expectations that have shifted as a result of e-commerce, shifting time structures with longer working hours for customers and business employees, and the presence of shopping centers. The planners support the opening of new gastronomic facilities, with more and more people looking to dine out rather than eat at home. All of these changes result in increased demands for comfortable shopping experiences. Customers desire a spatial and commercial infrastructure that eases running errands. They prefer services to be in close proximity to one another so that they can visit doctors, grocery stores, post offices, banks, and other shops all near their home. They want shopping to be a leisure activity, a sensory and haptic experience that they can enjoy during their limited free time. Since online shopping fosters new trends and fast-paced products, customers now desire shopping locations that offer a similarly large variety of (specialty and niche) businesses. Customer want stores to have long opening hours, and a large up-to-date stock that includes fresh,

77 Urban planner, $1.564 \mathrm{f}$. The city manager wants to "bring potential" to the street, "to develop" the street and its "potential" (1. 253, 373). 
organic, and sustainable products (food and non-food products both) within one - lifestyle appealing - location. ${ }^{78}$ Due to these new demands, many smaller stores on Karl-Marx-Straße are now struggling to survive economically.

Put together, the retail and gastronomic facilities along Karl-Marx-Straße face the challenge of changing neighborhood demographics and consumption patterns. The comparatively low purchasing power of the long-term residents, the urban renewal's numerous construction sites along the street, the heightened competition through e-commerce, adjacent shopping malls, new chain stores, and the rising commercial and residential rents have resulted in a shift toward a more lifestyle-oriented shopping experience that is also supported by the local urban renewal program. Certainly these factors, and the others discussed in the chapter, are only some of the factors that challenge and frame businesspeople' everyday life and daily work operations on Karl-Marx-Straße. But this chapter has outlined those challenges most often cited by the interviewed retail and planning experts and local shop owners. So while the district administration's main urban planner admits that his and his colleagues' "main focus is on the site's development" (1. 564 f.), this focus also holds true for the interviewed store owners.

Hence, it is in this contested socio-spatial context of contemporary Karl-MarxStraße, that independently owned gastronomic facilities, retailers, and other service providers are trying to align with the long-standing motto "trade is change" in the face of state-supported gentrification. Store owners frame change as something "natural" for cities and something that they must adapt to, or at least, that they have to "stick out" (flower store owner, 1. 503). But the urban renewal actors use the term "trade is change" to further discriminate against some of the smaller businesses, by downplaying the challenges that they face. Nevertheless, my research shows how against this backdrop of ongoing business threats and neighborhood change - local owners work for the development of the street as their common business site and as the "centers of their lives" (e.g. flower store owner, $781 \mathrm{ff}$.) through their everyday social practices. In Chapter 7, I present specific examples of business owners using everyday social practices to contribute to the development of Karl-Marx-Straße as an important, yet ordinary urban hub that secures integrated everyday life for all ethnic and social residential groups. But first, the next chapter introduces the sensitizing concepts that guided my case-selections: public characters and third places, interaction in semi-public or public spaces, and community building/ senses of belonging.

78 HDE (2013). German Retail. Facts and Figures. p.12 ff., http://www.einzelhandel.de/ index.php/presse/zahlenfaktengrafiken/item/110175-derdeutscheeinzelhandel.html, accessed 04/20/2016. 


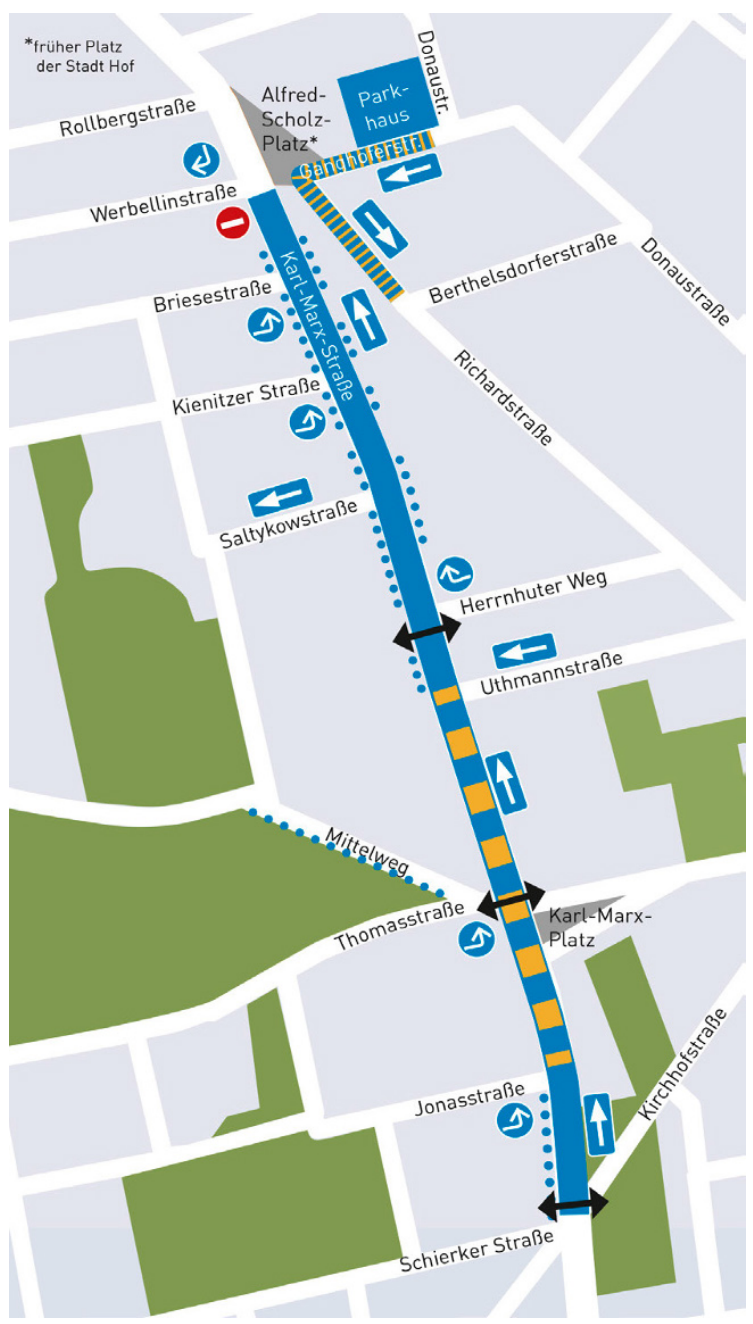

Fig. 13 Map showing the construction phases of Karl-Marx-Straße $\mathrm{e}^{79}$

79 The map indicates the different construction phases with the arrows indicating the new traffic directions and the orange color marking the construction site in 2014. In 2016, the construction site covers the entire blue colored strip. Source: Aktion! KarlMarx-Straße (n.d.). Handels-Newsletter Juli 2014, http://www.aktion-kms.de/files/ handelnews_juli2014_barr.pdf, accessed 03/31/2016. Courtesy: BSGmbH. 
Open Access This chapter is licensed under the terms of the Creative Commons Attribution 4.0 International License (http://creativecommons.org/licenses/by/4.0/), which permits use, sharing, adaptation, distribution and reproduction in any medium or format, as long as you give appropriate credit to the original author(s) and the source, provide a link to the Creative Commons license and indicate if changes were made.

The images or other third party material in this chapter are included in the chapter's Creative Commons license, unless indicated otherwise in a credit line to the material. If material is not included in the chapter's Creative Commons license and your intended use is not permitted by statutory regulation or exceeds the permitted use, you will need to obtain permission directly from the copyright holder.

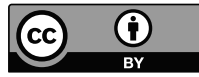

